Романенко Свген Олександрович, доктор наук з державного управління, професор, Заслужений юрист України, Президент Всеукраїнської асамблеї докторів наук 3 державного управління, Проректор 3 наукової роботи, Національний Авіаційний Університет, проспект Любомира Гузара, 1, Київ, 03058, тел.: (044)-408-53-33, e-mail: poboss1978@gmail.com, https//orcid.org/0000-0003-2285-0543

Помиткіна Любов Віталіївна доктор психологічних наук, професор, завідувач кафедри авіаційної психології Національного авіаційного університету, пр. Любомира Гузара, 1, м. Київ, 03058, тел.: (099) 138-4738, e-mail: Lyubvit@ukr.net, https://orcid.org/0000-0002-2148-9728

\title{
ОСОБЛИВОСТІ ФЕЛІНОТЕРАПІЇ ТА СПОСОБИ Iї̈ ЗАСТОСУВАННЯ
}

Анотація. Визначено, що грунтовних психологічних досліджень, які б переконливо доводили ефективність зоотерапевтичних втручань, у науковій літературі є обмаль, хоча в останні роки таких публікацій стає все більше, зважаючи на актуальність даного питання. Відмічено, що взаємодія з людини 3 тваринами має глибокий характер, що обумовлює ефективність використання анімалотерапії для лікування різноманітних психологічних i психофізіологічних травм. Доведено, що позитивний вплив тварин у сфері комплексу різних заходів по відновленню автономності, адаптації, працездатності і здоров'я людей з обмеженими фізичними і психічними можливостями в результаті перенесених (реабілітація) або вроджених (абілітація) захворювань є безперечним.

Проаналізовано, що у джерелах наукової літератури відмічається ефективність каніс- та фелінотерапії при ПТСР, як найбільш доступних та ефективних способів регуляції психоемоційних станів. Психокорекція із застосуванням цих різновидів зоотерапії не лише сприяє редукції симптомів ПТСР, але й $є$ ефективним психопрофілактичним засобом. Доведено, що симптоми ПТСР проявляються в поганому настрої, психоемоційних порушеннях (агресія, фрустрація, імпульсивність, обсесивно-фобічні розлади), що поєднуються з астенізацією та вегетативними порушеннями, спричиняють суб'єктивно погане самопочуття. Надмірна активність лише посилює стан виснаження і може бути розцінена як прояв зриву адаптаційних механізмів, порушення рівноваги між процесами гальмування та збудження. Знижені самопочуття та настрій, значно підвищені показники тривожності, агресії та ригідності, надмірна імпульсивність обумовлюють ризик асоціальної поведінки та дій, що можуть становити загрозу здоров'ю та життю як особі 3 
симптомами ПТСР, так i тих, хто іï оточує, що потребує відповідних лікувально-реабілітаційних заходів, розробки в комплексі цих заходів ефективних психокорекційних втручань.

Ключові слова: фелінотерапія, анімалотерапія, абілітація, підвищення психосоціальної адаптації, нормалізація самооцінки.

Romanenko Yevhen Oleksandrovych, Doctor of Science in Public Administration, Professor, Honored Lawyer of Ukraine, President of the AllUkrainian Assembly of Doctors of Science in Public Administration, Vice-Rector for Research, National Aviation University, 1 Lyubomyr Husar Avenue, Kyiv, 03058, tel .: (044) -408-53-33, e-mail: poboss1978@gmail.com, https // orcid.org / 00000003-2285-0543

Pomytkina Liubov Vitaliivna Doctor of Science, Professor, Head of the Department of Aviation Psychology at the National Aviation University, Liubomyra Huzara Ave., 1, Kyiv, 03058, tel.: (099) 138-47-38, e-mail: Lyubvit@ukr.net, https://orcid.org/0000-0002-2148-9728

\title{
FEATURES OF FELINOTHERAPY AND METHODS OF ITS APPLICATION
}

\begin{abstract}
It is determined that thorough psychological research, which would convincingly prove the effectiveness of zootherapeutic interventions, in the scientific literature is scarce, although in recent years such publications are becoming more and more, given the relevance of this issue. It is noted that the interaction with humans and animals is profound, which determines the effectiveness of animal therapy for the treatment of various psychological and psychophysiological traumas. It is proved that the positive impact of animals in the field of various measures to restore the autonomy, adaptation, ability to work and health of people with disabilities due to transferred (rehabilitation) or congenital (habilitation) diseases is undeniable.

It is analyzed that the sources of scientific literature note the effectiveness of canine and felinotherapy in PTSD, as the most accessible and effective ways to regulate psycho-emotional states. Psychocorrection with the use of these types of zootherapy not only helps to reduce the symptoms of PTSD, but is also an effective psychoprophylactic. It has been proven that the symptoms of PTSD are manifested in a bad mood, psycho-emotional disorders (aggression, frustration, impulsivity, obsessive-phobic disorders), combined with asthenia and autonomic disorders, cause subjective ill health. Excessive activity only exacerbates the state of exhaustion and can be seen as a manifestation of disruption of adaptation mechanisms, imbalance between the processes of inhibition and excitation. Decreased well-being and mood, significantly increased levels of anxiety, aggression and rigidity, excessive impulsiveness pose a risk of antisocial behavior and actions that can endanger the health and life of both a person with PTSD symptoms and those around him who
\end{abstract}


need appropriate medical treatment. -rehabilitation measures, development in a complex of these measures of effective psychocorrectional interventions.

Key words: felinotherapy, animal therapy, habilitation, increase of psychosocial adaptation, normalization of self-esteem.

Постановка проблеми. Фелінотерапія (кішкотерапія) - це метод лікування i профілактики захворювань, в основі якого лежить взаємодія людини 3 кішками. Домашні кішки живуть поруч 3 людьми вже більше 10 тисяч років. I якщо спочатку їх роль обмежувалася знищенням гризунів, то в подальшому кішка зайняла своє особливе місце, відмінне від інших домашніх тварин. Спілкування 3 кішкою допомагає людині розслабитися, зняти стрес, отримати задоволення від погладжування приємної вовни, від заспокійливого муркотіння [1; 2]. Про оздоровлюючі властивості кішки люди знають 3 глибокої давнини - фелінотерапія застосовувалася в Давньому Сгипті, Ассирії, Вавилоні, Римі. Багато культур почитали кішок, надавали котячу зовнішність своїм богам, наприклад, культ богині Бастет в Стародавньому Сгипті [3; 4]. 3 іншого боку, в різних країнах і в різні часи ставлення до кішок було далеко неоднозначним і варіювалося від любові до ненависті. Так, в середньовічній Європі кішку побоювалися, асоціюючи ії з відьмами і чаклунством.

Аналіз останніх досліджень і публікацій. На сьогодні особливості фелінотерапії досліджують як в соціогуманітарних напрямах (Ічанська О.М., Помиткіна Л.В., Хохліна О.П., Яковицька Л.С. та ін.) так і в технічних (Корольчук M.C., Фугелова T.A., Shevchuk D., Yakushenko O. а ін.).

Метою статті с висвітлення особливостей фелінотерапії для створення комфортної енергетичної обстановки.

Виклад основного матеріалу. Як показали медичні наукові дослідження, кішки сприятливо впливають на людину різними способами:

- За допомогою звуку - мова йде про муркотіння і органну вібрацію. Справа в тому, що кішки видають звуки на частоті від 16 до 44 Гц, - це оптимальна частота, яка сприятливо діє на організм - активізує його захисні функції і підвищує імунітет. Дивовижні властивості свого голосу кішки використовують як для самозцілення, так і для допомоги своїм господарям. Цікаво, що сеанси фелінотерапіі можна проводити і без участі кішок - просто прослуховуючи аудіозаписи котячого голосу.

- За допомогою тепла - температура котячого тіла 38-39 градусів, вона має м'який прогріваючий, заспокійливий і протизапальний ефект.

- За допомогою тваринної енергетики (Рис. 1). Це проявляється в тому, що кішка торкається до хворого місця людини або знаходиться поруч 3 тим, хто відчуває пригніченість і депресію.

- За допомогою тактильних відчуттів,- прогладжування кішки справляє заспокійливий ефект.

- За допомогою слабких електричних токів,- якщо провести рукою по шерсті кішки, можна відчути слабкі електричні розряди. 
- За допомогою масажу,- кішки люблять топтатися на тілі людини, при цьому відбувається масажна дія, а поколювання кігтями справляє ефект голковколювання.

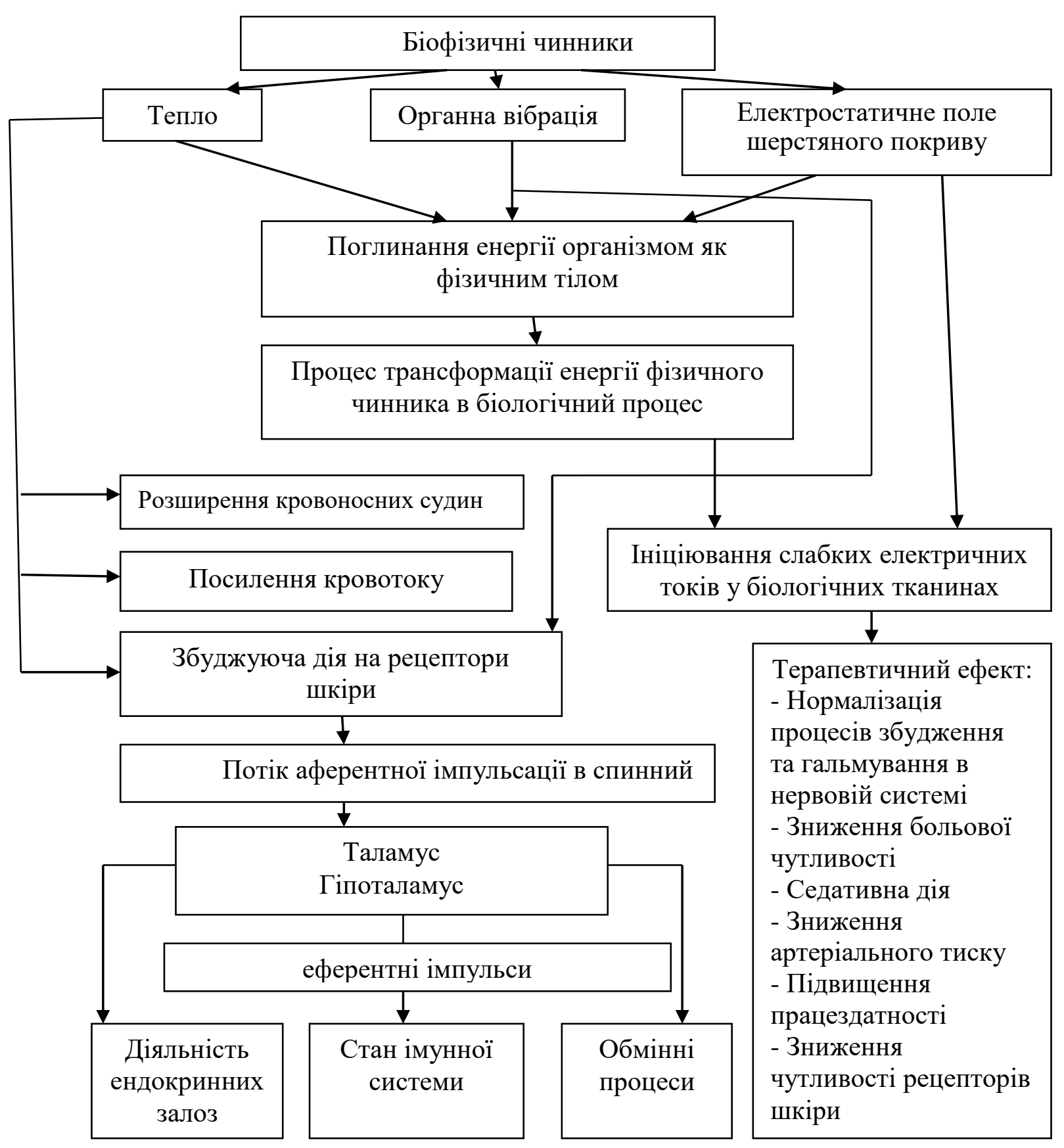

Рис. 1. Схема біофізичних ефектів фелінотерапії

Кількість захворювань, при яких можна використовувати фелінотерапію, дуже велике. Сюди відносяться онкологічні, серцево-судинні хвороби, синдром хронічної втоми, головний біль, депресії, неврози і багато інших. Помічено, що 
люди, які тримають кішок, мають більшу тривалість життя і менше схильні до захворювань.

Цінуючи здатності кішок справлятися 3 депресіями і згладжувати конфліктні ситуації, для створення комфортної енергетичної обстановки їх тримають в психіатричних клініках, готелях i навіть в офісах. Експерти китайської практики Фен-Шуй рекомендують заводити кішок для вирішення сімейних конфліктів, створення сприятливої енергетичної атмосфери в житловому просторі.

Схема впливу фелінотерапії на психоемоційні стани людини представлена на Рис. 2.

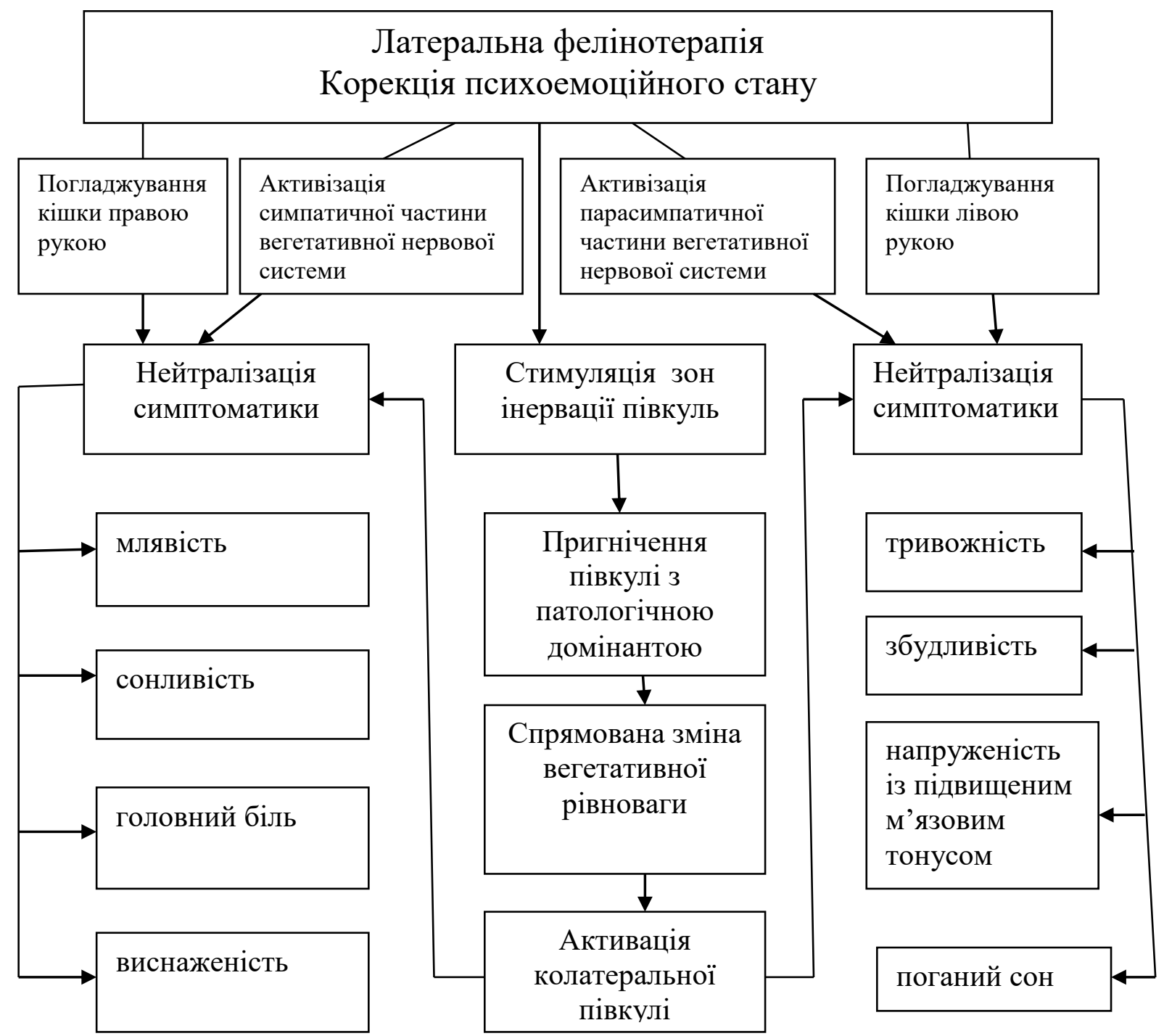

Рис. 2. Механізми впливу фелінотерапії на психоемоційні стани людини

Кішки здійснюють чудовий вплив на дітей, особливо корисне спілкування 3 кішками при віці дитини з 5-ти до 8-ми років. Як показують дослідження, такі діти мають гарний імунітет, стійку психіку, рідше хворіють і краще вчаться в школі. 
При застосуванні фелінотерапіі, необхідно враховувати протипоказання алергію на шерсть, неприязнь до кішок, шкірні захворювання, а також стани, пов'язані із загостренням психічних захворювань [5]. У загальному випадку, рекомендується дотримуватися наступного режиму проведення фелінотерапіі: щодня від 10 хвилин до 2 годин, для профілактики досить 1-2 разів на тиждень.

Для отримання найкращого результату від фелінотерапії, фахівці радять враховувати безліч факторів, пов'язаних із специфікою лікування конкретних захворювань:

- Час доби, в який відбувається контакт із кішкою - наприклад, хвороби легенів найкраще лікувати з 3 до 5 годин ранку, а серцево-судинні - 311 до 13 годин.

- Довжина вовни - довгошерсті кішки успішно лікують від безсоння, депресії, дратівливості. Середньошерсті найбільше підходять для людей із серцевими хворобами. Короткошерстні кішки допомагають при хворобах органів травлення та сечовидільної ситеми. Популярні в наш час кішкисфінкси допомагають при гінекологічних захворюваннях, хворобах печінки та нирок.

- Забарвлення кішки - чорні допомагають при хронічній втомі та неврозах, кремові - бадьорять, руді - заряджають позитивними емоціями, сіро-блакитні знімають стрес, різнокольорові - нормалізують артеріальний тиск і покращують настрій, а білі - універсальні засоби від усіх недуг.

- Стать тварини - кішки незамінні при протидії нервовим хворобам, нестійкій нервовій системі, а коти рекомендуються при радикуліті та артрозах.

Фелінотерапія є корисною при таких хворобах, як:

- Онкологічні захворювання,- кішка допомагає діагностувати місце пухлини, а також зменшити больові відчуття;

- Серцево-судинні захворювання,- муркотіння кішки сприяє нормалізації серцевого ритму;

- Синдром хронічної втоми,- прогладжування кішки «заряджає енергетикою»;

- Синдром залежностей,- муркотіння кішки знижує агресію;

- Хвороби органів травлення,- прогрівання за допомогою кішки дозволяє зняти спазми, зменшити біль,загалом полегшити стан хворого;

- Зубний біль,- контакт із кішкою має знеболюючий ефект;

- Невроз,- кішка сприяє зменшенню нападів панічних атак;

- Порушення артеріального тиску,- кішка сприяє регуляції артеріального тиску;

- Радикуліт,- корисним є зігріваючий ефект кішки;

- Порушення сну,- муркотіння кішки заспокоює та нормалізує сон; систему.

- Депресивний синдром,- заспокійливий вплив кішки на нервову

Важливо усвідомлювати, що користь від фелінотерапіі можна отримати тільки за умови любові і поваги до кішки - ні в якому разі не можна іiі 
змушувати лікувати. Фелінотерапія - це дивовижна методика, що дозволяє поєднати оздоровлення з позитивними емоціями, і при цьому дуже доступна.

Висновки. Підсумком теоретичного аналізу вищезазначеної проблеми $\epsilon$ те, що важливо усвідомлювати, що користь від фелінотерапіі можна отримати тільки за умови любові і поваги до кішки - ні в якому разі не можна іï змушувати лікувати. Фелінотерапія - це дивовижна методика, що дозволяє поєднати оздоровлення з позитивними емоціями, і при цьому дуже доступна.

\section{Лimepamypa:}

1. Фелинотерапия / Електронний ресурс.- режим доступу:https://tutknow.ru/psihologia/ 8082-chto-takoe-felinoterapiya.html

2. Фелінотерапія / Електронний ресурс.- режим доступу: http://ru.exrus.eu/ Фелинотерапия-id505207126ccc1949560001b9

3. Арушанян 3. Л. Как кошка в дом вошла. Начальные этапы формирования подвида кошка домашняя (Felis silvestris catus) / З. Л. Арушанян // Зоопрайс.- 2009.- №1-2 .

4. И создал Бог кошку, признаки доместикации домашней кошки / Електронний pecypc.- режим доступу: http://www.zooprice.ru/cat/history/i-sozdal-bog-koshku-domestikatsiyapodvida-felis-silvestris-catus-3.html

5. Федотова A. C. Зоогигиена: Метод. указания / А. С. Федотова.- Красноярск, 2014.- $25 \mathrm{c}$.

\section{References:}

1. Felinoterapija / Elektronnij resurs.- rezhim dostupu:https://tutknow.ru/psihologia/ 8082-chto-takoe-felinoterapiya.html

2. Felinoterapija / Elektronnij resurs.- rezhim dostupu: http://ru.exrus.eu/Felinoterapija-id505207126ccc1949560001b9

3. Arushanjan Z. L. Kak koshka v dom voshla. Nachal'nye jetapy formirovanija podvida koshka domashnjaja (Felis silvestris catus) / Z. L. Arushanjan // Zooprajs.- 2009.- №1-2 .

4. I sozdal Bog koshku, priznaki domestikacii domashnej koshki / Elektronnij resurs.rezhim dostupu: http://www.zooprice.ru/cat/history/i-sozdal-bog-koshku-domestikatsiya-podvidafelis-silvestris-catus-3.html

5. Fedotova A. S. Zoogigiena: Metod. ukazanija / A. S. Fedotova.- Krasnojarsk, 2014.- 25 s. 